\title{
Makna Pluralitas Agama di Kalangan Mahasiswa STAIN Kudus dan Implementasinya Melalui Mata Kuliah Perbandingan Agama
}

\author{
Efa Ida Amaliyah \\ Jurusan Ushuluddin STAIN Kudus \\ Jl. Conge No.51, Ngembalrejo, Kabupaten Kudus, Jawa Tengah, Indonesia \\ E-mail: efaida@gmail.com
}

\begin{abstract}
This article attempts to answer two questions concerning religious pluralism among students in STAIN Kudus. The first, "what is the meaning of religious pluralism from the student point of view?" The second, "how will the course of Comparative of Religion contributes to the religious pluralism among the students?" The result of this research shows that the students have their meanings and assumptions about religious pluralism depending on their knowledge and experiences. Detail of the findings are: first, religious pluralism means many different religions in Indonesia should be respected one another. Second, there is the attitude among students to respect and appreciate or to be tolerant to other religions. Third, there is the belief among students that all religions are good, but they still believe that the best and the true one is Islam. The majority of students define religious pluralism as respecting and appreciating other people's beliefs and doctrines. This understanding is needed to avoid horizontal conflict among the people in the grassroots. On the other side, the implementation of the concept of religious pluralism through Comparative of Religion course will give the insight to the students to balance between theory and practices.
\end{abstract}

Keywords:

Comparative of religion; meaning; religious plurality; student.

\begin{abstract}
Abstrak
Artikel ini mengungkap dua hal yang berkenaan tentang pluralitas agama atau pluralisme agama di kalangan mahasiswa STAIN Kudus, yaitu pertama, "bagaimana makna pluralitas agama di kalangan mahasiswa?" kedua, "bagaimana mata kuliah tersebut bisa memberikan kontribusi kepada mahasiswa tentang Pluralitas Agama?" Berdasarkan hasil penelitian di kalangan Mahasiswa STAIN Kudus, menyatakan bahwa mahasiswa memberi makna tentang pluralitas agama dengan beragam asumsi sesuai dengan pengalaman dan pengetahuan masing. Diantaranya adalah: pertama, dengan adanya pluralitas Agama keadaan yang menunjukkan adanya banyak macam Agama dan kita harus saling menghargai. Kedua, adanya sikap menghormati dan menghargai atau toleran pada Agama lain. Ketiga, suatu keyakinan yang menganggap semua Agama itu baik akan tetapi yang paling baik dan benar hanyalah Islam. Kebanyakan mahasiswa memaknai pluralitas agama yaitu menghargai dan menghormati keyakinan dan ajaran orang lain. Hal tersebut diperlukan untuk mengurangi konflik horizontal di kalangan masyarakat bawah (grass-root). Di sisi lain, implementasi konsep pluralitas agama melalui mata kuliah perbandingan agama, dapat memberikan pandangan pada mahasiswa untuk menyeimbangkan teori dan praktik di lapangan.
\end{abstract}

\section{Kata Kunci:}

Mahasiswa; makna; perbandingan agama; pluralitas agama.

DOI: $10.15575 / \mathrm{jw} . \mathrm{v} 2 \mathrm{i} 1.587$

Received: March 2016; Accepted: January 2017; Published: June 2017

\section{A. PENDAHULUAN}

Agama seperti dua sisi mata uang. Di sisi pertama, agama diandalkan sebagai basis moral bagi umat manusia. Agama mendoktrin manusia untuk hidup rukun dengan memegang teguh pesan ketuhanan kepada segenap manusia. Agama juga secara tegas menerangkan bahwa segala perbuatan manusia mempunyai konsekuensi, yaitu ganjaran (reward) dan hukuman (punishment). Agama dalam dimensi ini dipenuhi pesan keselamatan (salām) dan cinta kasih (rahmān-rahïm) bagi sesama makhluk. Pada sisi lain, agama sering dijadikan alat untuk melegitimasi atau melegalkan setiap bentuk kekerasan. Hal ini disebabkan karena ditafsirkan dan diadaptasi secara salah oleh pemeluknya. Dimensi ini yang menunjukkan 
wajah agama sebagai sesuatu yang sangat menakutkan. ${ }^{1}$

Agama tidak hanya sebagai dogma, tetapi juga disusun oleh berbagai kekuatan logika dan penafsiran, mitos, ekletisisme budaya yang dipraksiskan secara masif dan mengandung pada klaim kebenaran (truth claim). Kekerasan atas nama agama dengan menyiratkan sebentuk pengungkapan dan penafsiran pemeluknya terhadap pesan ke-Tuhan-an yang diikuti beragam mitos klaim kebenaran. Karenanya, pesan Tuhan gagal didialogkan dengan perkembangan peradaban manusia. ${ }^{2}$

Sudah menjadi sunnatullah kalau manusia itu diciptakan oleh Sang Pencipta dengan keadaan yang sangat beragam (pluralis), mulai dari berbeda bangsa, suku, adat istiadat, warna kulit, kebudayaan agama dan sebagainya. Dengan kondisi yang beragam itu manusia lalu berinteraksi satu sama lain. Dalam berinteraksi tersebut bisa menimbulkan sikap, perilaku dan pandangan yang berbeda-beda pula. Dengan sikap, perilaku dan pandangan yang berbeda-beda itu mereka bisa tetap hidup ${ }^{3}$ harmoni atau justru malah timbul konflik dan ketegangan. Misalnya di Sampit Kalimantan Tengah terjadi konflik karena perbedaan suku, di Poso, Ambon dan Maluku Tenggara terjadi konflik karena perbedaan suku dan agama, di Kashmir terjadi konflik karena perbedaan agama Hindu dan Islam, di Sri Lanka terjadi ketegangan karena perbedaan antara agama Buddha dan Hindu dan lain-lain.

Salah satu hal yang sering menimbulkan konflik dan ketegangan sosial adalah soal agama, karena ada umat agama yang mengklaim dirinya paling benar, yang lainnya sesat. Klaim ini kemudian melahirkan keyakinan yang biasa disebut dengan "doctrine of salvation" (doktrin keselamatan), bahwa keselamatan (surga) adalah hak para pengikut agama tertentu saja, sedangkan yang lainnya cela-

\footnotetext{
1 M. Kodim, "Kekerasan Atas Nama Agama," diakses pada 5 Juni 2011, https://pinggirmalam.wordpress.com/2008/06/25/kekerasan-atasnama-agama/.

${ }^{2}$ Kodim, "Kekerasan Atas Nama Agama."
} 3 ka dan akan masuk neraka. ${ }^{4}$ Konflik kadangkadang juga terjadi antara pemeluk agama yang sama, misalnya Katolik dan Protestan pada Agama Kristen, Mahayana dan Hinayana pada agama Buddha dan juga antar kelompokkelompok dalam Islam. Fenomena ini timbul akibat globalisasi dan karena kemajuan teknologi informasi di satu pihak serta bangkitnya berbagai gerakan kelompok agama di pihak lain, sehingga akan menambah melebarnya ketegangan.

Keanekaragaman di dunia modern memiliki banyak tantangan, terutama di level akar rumput (grass root). Dalam sebuah masyarakat terdiri dari berbagai kelompok seperti agama, budaya serta kelompok-kelompok yang mempunyai kepentingan dan memiliki orientasi sendiri.Secara faktual, konflik antara agama telah menyebar lebih besar dalam setiap masyarakat. Hal ini dapat kita lihat melalui media massa dan media elektronik setiap harinya. Konflik tersebut disebabkan dengan mengklaim bahwa agama mereka adalah yang terbaik.

Laporan tahunan yang dirilis CRCS (Center for Religious and Cultural Studies) UGM Yogyakarta tahun 2010, menyebutkan bahwa masalah mengenai rumah ibadah, laporan ini mencatat ada 39 rumah ibadah yang dipermasalahkan, sebagian besar adalah gereja yang dipermasalahkan kelompok-kelompok Muslim. Dari kasus tersebut CRCS menemukan sejumlah 32 kasus (82\%) menyangkut masalah antar umat beragama dan 4 kasus (10\%) konflik internal umat beragama. Beberapa hal yang memprihatinkan adalah masih adanya kekerasan fisik sebanyak 17 kasus (43\%). Persoalan ijin pendirian rumah ibadah masih menjadi isu utama dalam kasus-kasus rumah ibadah.Sebanyak 24 kasus (62\%) mengandung unsur tidak (belum) adanya ijin rumah ibadah tertentu. Kenyaataannya, ijin tak selalu menjadi alasan sebenarnya penentangan terhadap rumah ibadah. Kami memantau ada 4 kasus

\footnotetext{
${ }^{4}$ Anis Malik Thoha, Tren Pluralisme Agama, Tinjauan Kritis (Jakarta: Perspektif, 2005), 1.
} 
(10\%) rumah ibadah yang telah memiliki ijin namun tetap saja dipersoalkan ${ }^{5}$.

Mengenai tuduhan penyesatan, laporan ini mencatat ada 20 kasus di luar kasus Ahmadiyah. Dari 20 kasus yang ditemukan, sejumlah 17 kasus menyangkut umat Muslim, 1 kasus umat Buddha, 1 kasus umat Kristen dan 1 kasus lain menyangkut umat Hindu. Pada tingkat tertentu wacana penyesatan dan penodaan agama benar-benar menjadi bola liar yang bisa masuk ke segala urusan di mana wacana keagamaan mainstream menuduh, kadang dengan semena-mena, wacana tertentu telah menodai agama.Dari 20 kasus, ada 17 kasus tuduhan penodaan agama di mana masyarakat melibatkan polisi atau pemerintah. Hal ini sangat penting untuk memperkecil potensi kekerasan fisik yang dilakukan warga sipil. Dari 20 kasus itu pula masih terdapat 3 kasus di mana masyarakat masih mengedepankan kekerasan fisik ${ }^{6}$.

Untuk kasus yang paling banyak disorot adalah kasus Ahmadiyah. Media cetak dan elektronik sudah melaporkan tentang kekerasan yang dialami oleh kaum Ahmadiyah. Sebagaimana yang terjadi di Kuningan, Mataram (Nusa Tenggara Timur), Sulawesi, dan juga Sumatera Barat (Padang). Mereka sering dikafirkan oleh orang lain, karena dianggap sudah keluar dari ajaran Islam yang selama ini dikenal oleh kaum Muslim pada umumnya. Meskipun Ahmadiyah juga mengklaim bahwa mereka termasuk dalam Islam yang ada.

Pada laporan 2012 hanya memfokuskan pada pola permasalahan dari tiga topik terpilih yang terkait dengan tiga hal, yaitu: pertama, menyangkut presentasi pemerintah Indonesia di PBB dalam forum Universal Periodic Review (UPR) yang memunculkan pertanyaan dari dunia internasional mengenai permasalahan kebebasan beragama di Indonesia. $\mathrm{Ke}$ $d u a$, mengenai (tuduhan) penodaan agama yang sudah lama menjadi ganjalanutama

${ }^{5}$ Zainal Abidin Bagir, dkk, Laporan Tahunan Kehidupan Beragama di Indonesia (Yogyakarta: Yogyakarta: Center For Religious and Cultural Studies (CRCS), 2010), 11-12.

${ }^{6}$ Bagir, Laporan Tahunan Kehidupan Beragama Di Indonesia. hubungan antar- dan intra-agama di Indonesia, yang pada tahun 2012 mengalami peningkatan intensitas dan diikuti oleh tindakan kekerasan. Ketiga, menyangkut permasalahan rumah ibadah dengan memfokuskan pada tiga kasus, yaitu GKI Taman Yasmin Bogor dan gereja HKBP Filadelfi yang merupakan masalah lama namun hingga kini belum selesai, serta satu kasus baru yang terjadi di Aceh Singkil tahun 2012.

Pengkafiran juga sering dialamatkan untuk masyarakat penganut agama local (local religion atau local culture). Hal ini dianggap menyimpang dari agama yang sudah establish karena mempercayai selain Tuhan (beyond God), seperti percaya hal-hal yang berbau klenik $^{7}$. Konsekuensi ditimbulkan dari pengkafiran ini yaitu mereka "bertarung" dengan menggunakan ilmu-ilmu kebatinan dan tidak menggunakan kekerasan fisik.

Indonesia yang merupakan kawasan multi dalam berbagai hal (agama, etnis, bahasa, bahkan agama) rentan terhadap berbagai macam konflik. Fenomena yang beberapa kurun waktu terjadi menunjukan bahwa konflik yang diakibatkan agama sangat marak. Mereka mengklaim tentang kebenaran (truth claim), bahwa agama mereka yang paling benar, sehingga menganggap orang lain sebagai others yang harus diluruskan untuk sejalan dengan mereka.

Beberapa peristiwa mutakhir di Indonesia menunjukkan cukup beratnya tantangan dalam pengelolaan keragaman di Indonesia. Advokasi untuk pluralitas (atau apapun istilahnya untuk menyebut upaya menjadikan keragaman sebagai suatu kekayaan, bukan masalah, baik pada tingkat negara maupun masyarakat) telah cukup banyak dilakukan organisasi-organisasi masyarakat sipil, namun penting pula mengevaluasi strategi mereka dan melihat tantangan saat ini.

\footnotetext{
${ }^{7}$ Klenik adalah cerita-cerita aneh yang tidak berdasar pada kenyataan yang ada. Hal ini sama dengan cerita-cerita takhayul. Penganut klenik ini dianggap percaya pada hal-hal yang di luar kelumrahan dan kenalaran, sebagai contoh di Jawa bagian selatan, mereka percaya cerita tentang Nyi Roro Kidul dan menyakininya.
} 
Salah satu yang harus ikut berperan memikirkan sebagai bentuk tanggungjawab adalah mahasiswa. Hal ini dikarenakan mahasiswa sebagai agen perubahan (agent of change) dalam bersosialisasi dengan masyarakat. Mahasiswa harus mampu untuk menjawab tantangan yang ada dalam masyarakat dan memberikan sumbangan yang sangat berarti bagi lingkungan sekitarnya, termasuk konflik agama yang cenderung ke arah radikal yang memang sudah sering terjadi di Indonesia. Hal ini karena secara budaya, agama, dan etnis di Indonesia cukup beragam (multi). Karenanya, diperlukan sikap toleransi dengan tetap menjaga keyakinan yang sudah ada.

Dalam masyarakat, mahasiswa dianggap sebagai salah satu kelompok yang menjadi sub-elemen penting masyarakat sebab memiliki potensi besar dalam menciptakan suatu bentuk tatanan tertentu. Mahasiswa adalah manusia yang dipenuhi idealisme. Mahasiswa dianggap tunas-tunas baru yang akan menggantikan peran para pemimpin di masa yang akan datang. Di tangan para mahasiswa masa depan bangsa ini akan bergantung. Tongkat estafet kepemimpinan ini akan diteruskan oleh mahasiswa $^{8}$.

Di samping mahasiswa sebagai penerus kepemimpinan bangsa ini, ternyata mahasiswa berperan lebih besar sebagai agent of change. Potensi ini dipunyainya tidak terlepas dari tingkat pendidikannya yang tergolong tinggi dalam masyarakat. Beberapa sosiolog pendidikan, seperti Halsey dan Psacharopoulos menyatakan bahwa pendidikan memainkan bagian penting dalam determinan-determinan status dan penghasilan. Pendidikan yang tinggi akan mempengaruhi cara pandang, wawasan dan daya kritis yang memungkinkan mahasiswa untuk memikirkan masa depan masyarakat tempat mereka hidup, meminjam istilah William Fulbright, Education is slow but a

\footnotetext{
${ }^{8}$ Bahari, ed., Toleransi Beragama Mahasiswa (Studi tentang Pengaruh Kepribadian, Keterlibatan Organisasi, Hasil Belajar Pendidikan Agama, dan Lingkungan Pendidikan terhadap Toleransi Mahasiswa Berbeda Agama pada 7 Perguruan Tinggi Umum Negeri) (Jakarta: . Badan Litbang dan Diklat Puslitbang Kehidupan Keagamaan Kementerian Agama RI, 2010), 6.
}

powerful force. Karena tingkat pendidikan yang tinggi ini, pada akhirnya nanti, dari kalangan mahasiswa akan muncul tokoh-tokoh masyarakat yang akan berperan dominan dalam perkembangan masyarakat, termasuk dalam hal hubungan antar umat beragama ${ }^{9}$.

Paham pluralitas perlu disosialisasikan sedini mungkin kepada mahasiswa, agar mereka dapat merespon secepatnya terhadap kondisi yang terjadi di sekitar lingkungan mereka. Karenanya, mahasiswa perlu diberikan stimulus berupa materi-materi perkuliahan yang berhubungan dengan pluralitas. Ini perlu diberikan karena mereka belum pernah menerima materi tentang pluralitas secara formal atau secara mendalam. Mahasiswa sebagai agen perubahan harus dimanfaatkan untuk mentrasfer intelektualitas kepada masyarakat sebagai usaha untuk meminimalisasi kekerasan yang ditimbulkan oleh pengklaiman oleh pihak-pihak tertentu.Hal ini dikarenakan pengklaiman tersebut rentang terhadap disintegrasi bangsa, sehingga tercerabutnya asas-asas pancasila.

Mata kuliah Perbandingan Agama atau Ilmu perbandingan Agama adalah salah satu cabang ilmu pengetahuan yang berusaha untuk memahami gejala-gejala keagamaan dari suatu kepercayaan (agama) dalam hubungannya dengan agama lain. Pemahaman ini mencakup persamaan (kesejajaran) dan perbedaannya. Selanjutnya dengan pembahasan tersebut, struktur yang asasi dari pengalaman keagamaan manusia dan pentingnya bagi hidup dan kehidupan manusia dapat dipelajari dan dinilai $^{10}$.

Standar kompetensi atau tujuan mata kuliah ini adalah mahasiswa mampu untuk memahami tentang perbedaan agama dan mampu untuk diimplementasikan dalam kehidupan praktis. Hal ini karena sebuah keniscayaan

\footnotetext{
${ }^{9}$ Bahari, Toleransi Beragama Mahasiswa (Studi tentang Pengaruh Kepribadian, Keterlibatan Organisasi, Hasil Belajar Pendidikan Agama, dan Lingkungan Pendidikan terhadap Toleransi Mahasiswa Berbeda Agama pada 7 Perguruan Tinggi Umum Negeri), 6.

${ }^{10}$ A.Mukti Ali, Ilmu Perbandingan Agama (Sebuah Pembahasan tentang Methodos dan Sistema) (Yogyakarta: Yayasan Nida, 1975), 5.
} 
bahwa banyak agama di Indonesia. Diharapkan melalui mata kuliah ini mahasiswa tidak hanya berteori tentang beranekaragamnya agama tetapi mampu memberi solusi terhadap permasalahan yang sering terjadi yang bersumber dari perbedaan keyakinan tersebut.

Berdasarkan uraian diatas, maka tulisan ini mengungkap dua hal, yaitu: pertama, bagaimana makna Pluralitas Agama di kalangan mahasiswa? kedua, bagaimana mata kuliah tersebut bisa memberikan kontribusi kepada mahasiswa tentang Pluralitas Agama?

\section{B. HASIL DAN PEMBAHASAN}

Kerukunan umat beragama di Indonesia sudah terbina sejak zaman Kerajaan Majapahit sampai sekarang. Pada zaman orde baru konsep tentang kerukunan dan toleransi beragama disebut dengan istilah Trilogi Kerukunan, yaitu: kerukunan intern umat beragama, kerukunan antar umat beragama dan kerukunan antar penganut agama dengan pemerintah ${ }^{11}$. Tarmizi Taher menyebutkan bahwa ada empat macam komitmen yang patut dipegang oleh semua penganut agama untuk menciptakan kerjasama positif antar umat beragama di Indonesia, yaitu: (1) Komitmen terhadap budaya non-violence dan penghargaan terhadap kehidupan; (2) Komitmen terhadap budaya solidaritas dan keadilann ekonomi; (3) Komitmen terhadap budaya toleran dan hidup saling mempercayai, dan (4) Komitmen terhadap budaya persamaan hak dan kemitraan antara laki-laki dan perempuan ${ }^{12}$. Demikian juga Leonard Swidler, ahli Teologi Katolik mengatakan bahwa kita tidak dapat mengabaikan pihak lain dengan menutup mata, pikiran dan hati terhadap mereka. Juga tidak dapat menatap mereka denga rasa curiga, prasangka dan bahkan terkadang dengan kebencian. Pola hubungan semacam ini hanya akan mengantar kepada permusuhan yang berakhir dengan pola monolog, bukan pola dialog. Siapa saja

\footnotetext{
${ }^{11}$ Tarmizi Taher, Menuju Umatan Wasathan Kerukunan Beragama di Indonesia (Jakarta: Pusat Pengkajian Islam dan Masyarakat, 1998), 50-51.

${ }^{12}$ Tarmizi Taher, Menjadi Muslim Moderat, Beragama di Tengah Peradaban Global (Jakarta: Hikmah, 2004), 27.
}

yang akan mengabaikan dialog akan tergusur sendiri ${ }^{13}$.

Pluralisme agama atau pluralitas agama sudah banyak dikampanyekan oleh berbagai kalangan yang peduli terhadap kebersamaan dan kesetaraan dalam berbagai hak asasi. Mereka berkeyakinan bahwa semua manusia sama dalam hal apapun, seperti derajat sosial, ekonomi, agama, budaya, dan lainnya. Hal yang membuat berbeda diantara mereka hanyalah tingkat ketakwaan atau keimanan dari perspektif agama apapun.

\section{Makna Pluralitas Agama atau Plural- isme Agama}

Mahasiswa STAIN Kudus memberi makna pluralitas agama atau pluralisme agama sangat beragam. Hal tersebut sesuai dengan pengetahuan mereka tentang konsep tersebut dengan melihat fenomena atau realita di sekitar mereka. Konflik yang terjadi akibat perbedaan dan persepsi tentang agama berdampak langsung dalam kehidupan sehari-hari. Meskipun demikian, mahasiswa STAIN Kudus yang kebanyakan berasal dari Kudus dipengaruhi oleh sosok yang menyebarkan konsep pluralitas agama dan multikultural, yaitu Sunan Kudus.

Beberapa makna tentang pluralitas agama atau pluralisme agama sebagai berikut:

a. Dengan adanya pluralitas Agama keadaan yang menunjukkan adanya banyak macam Agama dan kita harus saling menghargai;

b. Suatu sikap menghormati dan menghargai atau toleran pada Agama lain;

c. Suatu keyakinan yang menganggap semua Agama itu baik akan tetapi yang paling baik dan benar hanyalah Islam. Tidak ada makna tentang pluralitas agama.

Pemaknaan yang diberikan mahasiswa paling tidak tersimpulkan dalam tiga kategori. Kategori pertama sebagai sikap menerima (acceptance), kelompok ini tidak berhubungan langsung dengan pemahaman keberagamaan. Mereka bersikap netral dan selalu bersikap positif terhadap ide atau pembaharuan. Menurut mereka biarkan saja sebuah perkembangan berjalan apa adanya dan suatu saat akan berhenti dan jenuh tanpa diberhenti-

\footnotetext{
${ }^{13}$ Leonard Swidler, Death or Dialoge (Minneapolis: Fortress Press, 1993), 24.
} 
kan secara paksa. Semua perubahan tergantung pada masyarakat yang harus pintar dan cerdas menilai. Masyarakat yang cerdas berpikiran ke depan dengan memperhitungkan baik dan buruknya. Kalaupun terjadi konflik, hal tersebut karena dalam proses pencerahan dan juga proses pencerdasa.

Kategori kedua yaitu sikap menolak (resistance), hal ini ketika menanggapi konsep pluralitas atau plurlisme agama masih terkait dengan dengan tingkat pemahaman keberagamaan mereka. Alasan penolakan cenderung mengkritik tentang konsep relativisme kebenaran dalam pluralisme agama. Mengakui kebenaran pada agama lain adalah keliru. Allah menjadikan Islam sebagai agama terakhir dan Muhammad sebagai nabi akhir zaman. Sebagai seorang Muslim, maka harus percaya bahwa Islam adalah agama yang paling benar dari semua agama. Namun dengan keyakinan tersebut tidak berarti ada hak atau izin untuk berbuat semena-mena terhadap agama dan pemeluk lainnya.

Kategori ketiga yaitu sikap yang raguragu. Mahasiswa yang mempunyai sikap ini tidak mempunyai makna apapun. Bagi mereka, pluralitas agama tidak ada maknanya karena tidak berpengaruh terhadap kehidupan sosial mereka. Hidup sudah ditentukan menurut takdirnya masing-masing. Jadi tidak perlu ada perdebatan antar agama karena perdebatan akan menimbulkan konflik. Sikap mahasiswa yang seperti ini meminjam istilah Sigmund Freud sebagai bentuk pertahanan diri untuk menutup kecemasan melalui pemutarbalikan kenyataan tetapi hanya mengubah persepsi dari masalah tersebut.

Meskipun demikian, beberapa mahasiswa masih mempunyai sikap inklusif-ekslusif yaitu sikap yang memang terbuka dengan perbedaan tetapi tetap menganggap bahwa agama Islam lah yang paling benar. Dalam hal tersebut sama seperti sebagaimana bahasa yang digunakan Hans Kung bahwa agama harus dilihat dari luar (eksternal religius) dalam hubungannya dengan pluralisme agama dan sekaligus dari dalam (internal religius), yaitu Alquran secara eksternal memandang setiap agama sebagai jalan yang bersifat relatif namun secara internal, Islam harus dipandang sebagai agama terbenar yang memiliki nilai kemutlakan.

Menurut para Neo-Modernis, ada beberapa langkah untuk terciptanya makna tentang pluralisme agama dan menghindari konflik. Pertama, dialog teologis-spiritual. Dialog ini memperoleh arti yang sesungguhnya apabila disertai oleh keberanian para pemeluknya mempertanyakan, menggugat dan mengoreksi diri sendiri sesudah memahami jantung pengalaman keagamaan orang lain. Jika ini dapat dilakukan, maka akan lahir pandangan keagamaan yang inklusif, terbuka dan tidak mudah menyalahkan keyakinan keagamaan orang lain. Model ini sering diistilahkan dengan dialog intrareligius (intrareligius dialoge).

Kedua, dialog sosial kemanusiaan, artinya antar pemeluk agama membicarakan masalah agama dan hubungannya dengan problem kemanusiaan yang terjadi, yang kemudian berusaha secara bersama-sama mencari alternatif pemecahannya. Dalam dialog ini, agamaagama dimintai responnya terhadap problem sosial kontemporer, yang tidak lain hal ini menuntut peran kritis agama. Dalam hubungan ini tidak jarang terjadi persamaan persepsi dan visi masing-masing agama.

Mahasiswa memberi pemaknaan tersebut sama seperti yang disampaikan oleh George F. Hourani dengan menggunakan prinsip etika pluralisme, yaitu;

a. Prinsip toleransi (tasamuh) dan kompetisi dalam kebaikan (fastabiq al-khairat). Toleransi adalah sikap meneggang (menghargai, membiarkan, membolehkan) pendirian (pendapat, pandangan, kepercayaan, kebiasaan dan sebagainya) yang berbeda atau bertentangan dengan pendirian sendiri. Akar-akar toleransi yang dirujuk dari teks kitab suci Al-Quran memiliki beberapa prinsip; (a) perbedaan (keragaman) keyakinan adalah kehendak Allah yang perennial; (b) bahwa pengadilan dan hukuman bagi keyakina yang salah harus diserahkan kepada Allah sendiri. Tuhan lebih tau siapa yang menyimpang dari jalan-Nya dan siapa yang mendapat petunjuk; (c) keyakinan 
kepada sebuah agama fitrah. Agama fitrah tidak hanya bermakna agama Islam, tetapi juga bermakna agama asal-usul umat manusia., yang melekat, dan dicapkan secara tak terhapuskan pada jiwa manusia, ini bearti bahwa setiap manusia terikat dalam suatu persaudaraan, keagamaan universal, karena masing-masing agama Allah yang tertanam dalam diri manusia berupa dinfitrah (agama asal manusia) ${ }^{14}$.

b. Prinsip saling menghormati, kerja sama, dan pertemanan. Prinsip ini merupakan implikasi sosiologis ketiga prinsip sebelumnya. Prinsip ini sangat ditekankan dalam Al-Quran karena dipandang sama dengan menghormati agama sendiri. Sebaliknya mencaci agama lain sama dengan mencaci agama sendiri.

c. Prinsip ko-eksistensi damai (al-ta'ayush alsilmi). Prinsip ini merupakan dasar hubungan antara manusia sesuai dengan arti generic Islam itu sendiri, yaitu damai. Oleh karena itu, menerima Islam sebagai agama, konsekuensinya menerima ko-eksistensi damai sebagai pokok ajarannya ${ }^{15}$.

d. Dialog yang arif-konstruktif-transformatif (munajat bi al-hasan). Ini merupakan konsekuensi dari prinsip kelima. Dalam implementasinya, sepuluh pedoman dasar dialog antar agama dari Leonard Swidler dapat dijadikan penafsiran yang baik berkenaan dengan dialog bi al-lati hiya ahsan. Kesepuluh dasar dialog tersebut adalah; (1) bahwa tujuan awal proses dialog adalah untuk berubah, dan tumbuh dalam persepsi yang benar tentang kenyataan dan selanjutnya bertindak secara tapat; (2) dialog harus merupakan proyek dua sisi: pertama, dialog dalam komunitasnya sendiri, dan selanjutnya dialog dengan komunitas lain; (3) setiap partisipan yang memasuki proses dialog ini harus mempercayai ketulusan dan kejujuran rekan dialognya; (4) dalam dialog tidak boleh melakukan perbandingan atas

\footnotetext{
${ }^{14}$ Ngainu Na'im, Teknologi Kerukunan: Mencari Titik Temu dalam Keragaman (Yogyakarta: Teras, 2011), 53.

${ }^{15}$ Na'im, Teknologi Kerukunan: Mencari Titik Temu dalam Keragaman, 54.
}

ideal-ideal agama kita dengan praktik/ kenyataan agama patner dialog kita; (5) setiap partisipan dialog harus mendefinisikan dirinya sendiri-sebab dalam kenyataannya suatu agama hanya bisa didefinisikan oleh agama itu sendiri-sebaliknya setiap definisi diri yang ditafsirkan oleh patner dialog kita harus diterima dengan lapang dada, sebagai upaya untuk mengenal diri lebih baik; (6) masing-masing partisipan dialog harus menahan diri justru untuk mencari pokok-pokok perbedaan yang ada; (7) dialog hanya bisa terjadi parcum pari, yaitu antara pihak-pihak yang selevel; (8) proses dialog itu hanya bisa berlangsung melalui basis saling percaya; (9) setiap pribadi yang terlibat dalam dialog harus bisa mengambil sikap kritis, minimal atas dirinya sendiri (gagasan-gagasannya) dan tradisi religious yang diyakininya; (10) setiap partisipan harus berusaha memahami agama dan patner dialognya "dari dalam". Kesadaran terhadap pluralitas dapat melahirkan sikap toleran. Toleransi inilah menjadi modal penting bagi terciptanya kehidupan damai tanpa konflik.

\section{Implementasi Pluralitas Agama atau Pluralisme Agama Melalui Mata Kuliah Perbandingan Agama}

Indonesia mempunyai agama yang banyak (plural) dengan jumlah agama yaitu enam agama (Islam, Kristen Katolik, Protestan, Hindu, Buddha, dan Konghucu). Melihat fenomena tersebut, maka akan muncul sifat "egois" yang dimiliki masing-masing umat agama tersebut. Kondisi tersebut terjadi di kalangan masyarakat bawah, karena mereka memang hidup berdampingan. Karenanya diperlukan sikap saling menghargai dan menghormati mutlak diperlukan untuk menjaga keharmonisan dalam bersosialisasi.

Silabi STAIN Kudus untuk Jurusan Tarbiyah salah satu mata kuliahnya adalah Perbandingan Agama. Mata kuliah ini merupakan Mata Kuliah Keahlian Berkarya (MKB). Sebagaimana yang didefinisikan oleh Mukti Ali bahwa perbandingan agama adalah cabang ilmu pengetahuan yang berusaha untuk 
memahami gejala-gejala keagamaan dari suatu kepercayaan (agama) dalam hubungannya dengan agama lain. Pemahaman ini mencakup persamaan dan perbedaannya. Selanjutnya dengan pembahasan tersebut, struktur yang asasi dari pengalaman keagamaan manusia dan pentingnya bagi hidup dan kehidupan manusia dapat dipelajari dan dinilai.

Menurut Fahruddin Faiz ${ }^{16}$, dasar pemikiran dalam pengelompokan mata kuliah mempunyai hubungan dengan kurikulum, persyaratan kerja dan UNESCO, sebagaimana yang terlihat dalam tabel berikut:

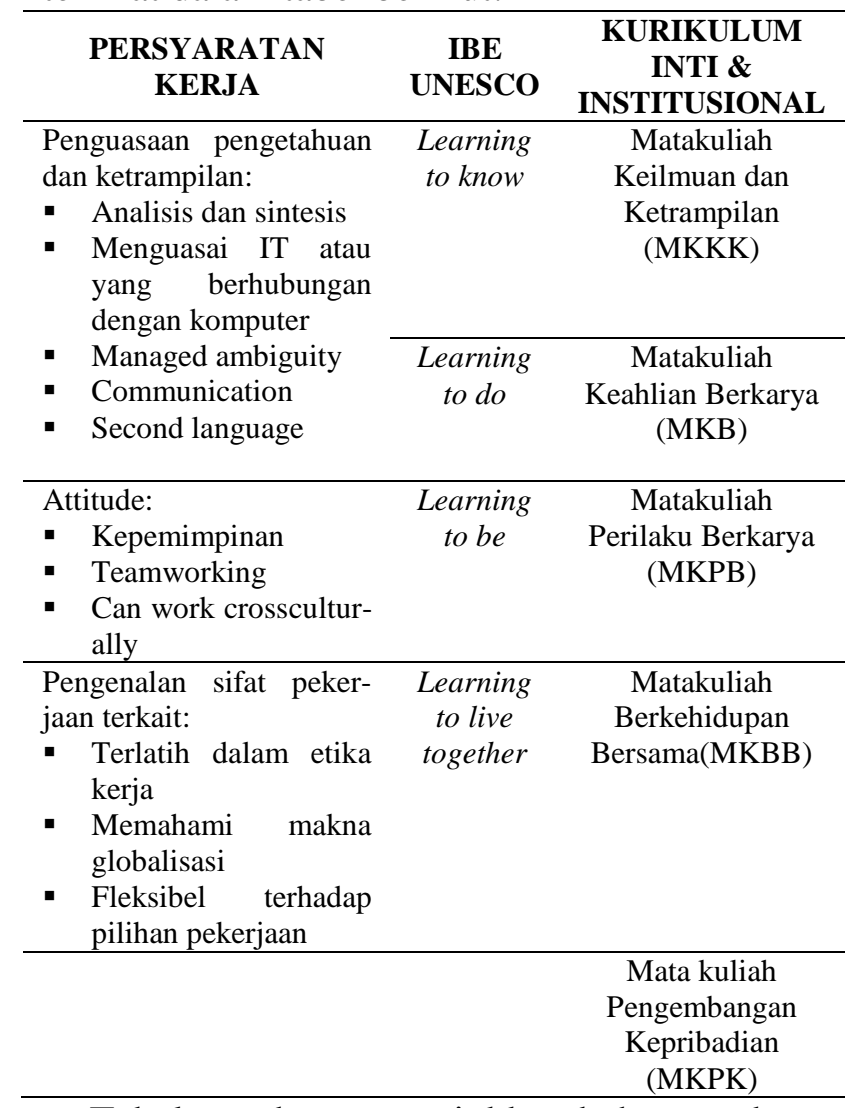

Tabel tersebut menunjukkan bahwa perbandingan agama termasuk dalam katageri mata kuliah keahlian berkarya (MKB), yang menurut UNESCO masuk dalam kategori learning to do yaitu belajar untuk melakukan. Silabi mata kuliah Perbandingan agama salah satu poinnya adalah mahasiswa mempelajari agama-agama lain. Hal ini otomatis membuka

\footnotetext{
${ }^{16}$ Fahrudidn Aziz, "Redesain kurikulum Prodi Ilmu Aqidah Jurusan Ushuluddin STAIN Kudus", paper untuk kegiatan workshop peningkatan akreditasi dan desain kurikulum Prodi Ilmu Aqidah Jurusan Ushuluddin STAIN Kudus (Kudus, 2013).
}

ruang bagi mereka untuk mempelajari agamaagama lain. Inilah yang kemudian harus memiliki sikap menghormati dan menghargai agama lain, sehingga nilai-nilai pluralitas otomatis harus dimiliki mahasiswa. Hal ini mengingat STAIN merupakan sekolah tinggi Islam yang memang mahasiswanya beragama Islam, sehingga sangat bermanfaat apabila mereka melihat dan menemukan ajaran selain Islam. Berdasarkan pengetahuan, mahasiswa sudah mempunyai makna tentang pluralitas agama dan mengerti tentang konsep tersebut.

Mata kuliah perbandingan agama tersebut selayaknya tidak hanya berisi tentang teori yang ada, tetapi juga harus diimbangi field research untuk menambah wawasan dan kepekaan jiwa sosial mereka. Hal tersebut perlu diapresiasi oleh pihak kampus, agar nilai-nilai sosial mampu teraplikasikan. Nilainilai tersebut antara lain, 1) kasih-sayang (terdiri dari pengabdian, tolong-menolong, kesetiaan dan kepedulian, 2) responsibility (rasa memiliki, disiplin dan empati), 3) life harmony (keadilan toleransi, kerjasama). Nilai-nilai inilah yang dibutuhkan dalam penanganan dan memaknai pluralitas agama, sehingga pluralitas agama yang sudah dan akan terjadi tidak menjadi "teror" atau "ketakutan" bagi masyarakat Indonesia, karena memang secara nyata tidak bisa terhindarkan lagi. Dengan demikian, pluralitas agama akan selalu disikapi se-objektif mungkin bagi siapapun yang memiliki kepedulian pada permasalahan sosial.

Menurut Ratnaasyu Sitaresmi sebagaimana yang dikutip oleh Nur Said ${ }^{17}$ memperkenalkan paradigma pluralitas agama, pluralisme agama atau multikulturalisme kepada anak dilakukan melalui dua tahap. Tahap pertama, secara langsung, yaitu dengan menyampaikan pesan multikulturalisme secara langsung dengan contoh konkrit dalam kehidupan sehari-hari. Tahap kedua, yaitu secara tidak langsung, maksudnya adalah dengan menyampaikan cerita yang berisi pesan tentang multikulturalisme dengan mengajak berimajinasi kreatif melalui dongeng, fabel (cerita hewan), dan mitos.

\footnotetext{
${ }^{17}$ Nur Said, Jejak Perjuangan Sunan Kudus dalam Membangun Karakter Bangsa (Kudus: Brillian Media Utama, 2010), 167.
} 
Mahasiswa merupakan masyarakat dewasa yang mampu berfikir secara kritis dan rasional. Mereka mampu membaca fenomena yang ada di lingkungan sekitar, sehingga jiwa mereka akan terusik ketika ada kekacauan (chaos) terjadi. Karenanya, untuk mengimbangi antara teori dan praktek, mahasiswa membutuhkan kegiatan yang nyata untuk mendukung teori tersebut, yaitu dengan mengaplikasikan langsung dalam kehidupan seharihari.

Hal tersebut terungkap dalam pendapat mahasiswa tentang konsep pluralitas agama yang diimplementasikan dalam mata kuliah perbandingan agama. Berikut pendapat mahasiswa:

a. Kunjungan ke tempat-tempat ibadah.

Berkunjung ke tempat ibadah umat agama lain perlu dilakukan. Hal ini untuk mengetahui secara pasti kondisi agama lain secara langsung, sehingga memunculkan sikap life-harmony dan menambah wawasan mahasiswa.

b. Memupuk sikap saling menjaga kerukunan intern, antar, dan intern antar umat beragama.

c. Dialog antar umat beragama dalam rangka dakwah dan kemaslahatan bersama.

d. Mencari dan menemukan segi-segi persamaan atau kesejajaran dan perbedaan antara Agama Islam dengan agama-agama selain Islam.

e. Menumbuhkan rasa simpati terhadap orang-orang yang belum mendapat petunjuk tentang kebenaran ajaran Agama.

Beberapa mahasiswa yang mendapatkan mata kuliah perbandingan agama mempunyai pengalaman yang berbeda. Hal tersebut tergantung kepada masing-masing dosen pengampu yang mengajar. Ada dosen yang memang hanya mengajarkan teori-teori tentang agama sesuai dengan silabi yang tersedia, tetapi ada juga dosen pengampu yang mampu mengajak mahasiswa untuk secara langsung berinteraksi dengan umat lain dari agama lain, hal ini untuk mempertegas kepada mahasiswa bahwa mereka hidup dengan beragam latar belakang, baik ekonomi, pendidikan, sosial, budaya, dan juga agama.
Karenanya, sangat penting sekali untuk mengajak mereka ke kalangan grass-root sebagai langkah awal bahwa mereka adalah agent of change yang bisa menentukan masa depan kehidupan masyarakat luas.

\section{SIMPULAN}

Pluralitas agama atau pluralisme agama merupakan suatu kondisi di mana segala ragam corak dan warna terhimpun dan lebur menjadi satu ragam baru, melainkan dibiarkan untuk memperkaya dinamika ragam yang ada. Dalam kehidupan beragama, pluralitas merupakan keyakinan bahwa kebenaran terdapat dalam berbagai agama. Tidak ada kebenaran tunggal.

Salah satu yang harus ikut berperan memikirkan sebagai bentuk tanggungjawab adalah mahasiswa. Hal ini disebabkan mahasiswa sebagai agen perubahan (agent of change) dalam bersosialisasi dengan masyarakat. Mahasiswa harus mampu untuk menjawab tantangan yang ada dalam masyarakat dan memberikan sumbangan yang sangat berarti bagi lingkungan sekitarnya, termasuk konflik agama yang cenderung ke arah radikal yang memang sudah sering terjadi di Indonesia.Hal ini karena secara budaya, agama, dan etnis di Indonesia cukup beragam (multi). Karenanya, diperlukan sikap toleransi dengan tetap menjaga akidah/keyakinan yang sudah ada.

Hal tersebut terungkap dalam pendapat mahasiswa tentang konsep pluralitas agama yang diimplementasikan dalam mata kuliah perbandingan agama. Berikut pendapat mahasiswa, antara lain, pertama, kunjungan ke tempat-tempat ibadah. Berkunjung ke tempat ibadah umat lain perlu dilakukan. Hal ini untuk mengetahui secara pasti kondisi agama lain, sehingga memunculkan sikap lifeharmony dan menambah wawasan mereka. Kedua, memupuk sikap menjaga kerukunan intern, antar, dan intern antar umat beragama. Ketiga, Dialog antar umat beragama dalam rangka dakwah dan kemaslahatan bersama. Keempat, Mencari dan menemukan segi-segi persamaan dan perbedaan antara Agama Islam dengan agama-agama bukan Islam. Kelima, Menumbuhkan rasa simpati terhadap orang- 
orang yang belum mendapat petunjuk tentang kebenaran ajaran Agama

Pada akhirnya pluralisme dan pluralitas agama membutuhkan komitmen yang nyata dan partisipasi serta penyesuaian diri dari seseorang atau kelompok serta semangat orang lain atau kelompok lain. Dalam konteks pluralisme agama komitmen kebersamaan tidak harus menghilangkan komitmen religious masing-masing.Hal tersebut sesuai dengan konsep pluralisme agama yaitu pluralitas didasarkan pada perbedaan bukan persamaan.

Komitmen kebersamaan dalam menjaga keharmonisan dalam perbedaan sangat dibutuhkan. Perdamaian tidak akan tercapai tanpa ada rasa saling menghormati dan menjunjung tinggi rasa kebersamaan dalam masyarakat. Keharmonisan bermasyarakat sangat bergantung bagaimana seseorang

\section{DAFTAR PUSTAKA}

Ali, A.Mukti. Ilmu Perbandingan Agama (Sebuah Pembahasan Tentang Methodos Dan Sistema). Yogyakarta: Yayasan Nida, 1975.

Aziz, Fahrudidn. "Redesain Kurikulum Prodi Ilmu Aqidah Jurusan Ushuluddin STAIN Kudus." Kudus, 2013.

Bagir, Zainal Abidin. Laporan Tahunan Kehidupan Beragama Di Indonesia. Yogyakarta: Yogyakarta: Center For Religious and Cultural Studies (CRCS), 2010.

Bahari, ed. Toleransi Beragama Mahasiswa (Studi Tentang Pengaruh Kepribadian, Keterlibatan Organisasi, Hasil Belajar Pendidikan Agama, Dan Lingkungan Pendidikan Terhadap Toleransi Mahasiswa Berbeda Agama Pada 7 Perguruan Tinggi Umum Negeri). Jakarta: . Badan Litbang dan Diklat Puslitbang Kehidupan Keagamaan Kementerian Agama RI, 2010.

Na'im, Ngainu. Teknologi Kerukunan: Mencari Titik Temu Dalam Keragaman. menghargai perbedaan dan berusaha menjaga diri untuk saling mendominasi.

Hendaknya setiap mata kuliah memberi makna bagi mahasiswa. Mata kuliah Perbandingan Agama hendaknya dijadikan pijakan awal untuk mengenalkan tentang pluralism. Standar kompetensi atau tujuan mata kuliah ini adalah mahasiswa mampu untuk memahami tentang perbedaan agama dan mampu untuk diimplementasikan dalam kehidupan praktis. Hal ini karena sebuah keniscayaan bahwa banyak agama di Indonesia. Diharapkan melalui mata kuliah ini mahasiswa tidak hanya berteori tentang beranekaragamnya agama tetapi mampu memberi solusi terhadap permasalahan yang sering terjadi yang bersumber dari perbedaan keyakinan tersebut.

Yogyakarta: Teras, 2011.

Said, Nur. Jejak Perjuangan Sunan Kudus Dalam Membangun Karakter Bangsa. Kudus: Brillian Media Utama, 2010.

Swidler, Leonard. Death or Dialoge. Minneapolis: Fortress Press, 1993.

Taher, Tarmizi. Menjadi Muslim Moderat, Beragama Di Tengah Peradaban Global. Jakarta: Hikmah, 2004.

-. Menuju Umatan Wasathan Kerukunan Beragama Di Indonesia. Jakarta: Pusat Pengkajian Islam dan Masyarakat, 1998.

Thoha, Anis Malik. Tren Pluralisme Agama, Tinjauan Kritis. Jakarta: Perspektif, 2005.

\section{Internet}

Kodim, M. "Kekerasan Atas Nama Agama." Diakses pada 5 Juni 2011. https://pinggirmalam.wordpress.com/200 8/06/25/kekerasan-atas-nama-agama/. 